\title{
REINFORCEMENT OF UNDERGROUND EXCAVATION WITH EXPANSION SHELL ROCK BOLT EQUIPPED WITH DEFORMABLE COMPONENT
}

\author{
WALDEMAR KORZENIOWSKI, KRZYSZTOF SKRZYPKOWSKI \\ AGH University of Science and Technology, Faculty of Mining and Geoengineering, \\ al. Mickiewicza 30,30-059 Kraków, Poland, e-mail: walkor@agh.edu.pl, skrzypko@agh.edu.pl
}

\section{KRZYSZTOF ZAGÓRSKI}

AGH University of Science and Technology, Faculty of Mechanical Engineering and Robotics, al. Mickiewicza 30, 30-059 Kraków, Poland, e mail: zagkrzys@agh.edu.pl

\begin{abstract}
The basic type of rock mass reinforcement method for both preparatory and operational workings in underground metal ore mines, both in Poland and in different countries across the world, is the expansion shell or adhesive-bonded rock bolt. The article discusses results of static loading test of the expansion shell rock bolts equipped with originally developed deformable component. This component consists of two profiled rock bolt washers, two disk springs, and three guide bars. The disk spring and disk washer material differs in stiffness. The construction materials ensure that at first the springs under loading are partially compressed, and then the rock bolt washer is plastically deformed. The rock bolts tested were installed in blocks simulating a rock mass with rock compressive strength of $80 \mathrm{MPa}$. The rock bolt was loaded statically until its ultimate loading capacity was exceeded. The study presents the results obtained under laboratory conditions in the test rig allowing testing of the rock bolts at their natural size, as used in underground metal ore mines. The stress-strain/displacement characteristics of the expansion shell rock bolt with the deformable component were determined experimentally. The relationships between the geometric parameters and specific strains or displacements of the bolt rod were described, and the percentage contribution of those values in total displacements, resulting from the deformation of rock bolt support components (washer, thread) and the expansion shell head displacements, were estimated. The stiffness of the yielded and stiff bolts was empirically determined, including stiffness parameters of every individual part (deformable component, steel rod). There were two phases of displacement observed during the static tension of the rock bolt which differed in their intensity.
\end{abstract}

Key words: rock bolting, expansion shell rock bolt stiffness, deformable component, mining

\section{INTRODUCTION}

Rock bolts used in the underground mining can be divided into three types: adhesive-bonded, mechanically expanded, and frictional [21]. This type of rock mass support fulfils its function when it works together with the adequately selected elements protecting the workings [19], [25], [35]. As regards exploitation workings, the load bearing washers play a specific role as they transfer the loads of the bolt rod to the roof surface, at the same time compressing the package of rocks being bolted [8], [16], [27], [36].

The search for the solutions to increase the deformability of underground excavation support, including rock bolts, has a relatively long history. In Poland, the rock bolt support with a rubber head was used as early as the 1970s. A deformable rubber bushing was used instead of the mechanical head [1], [14], [34], increasing the deformability of expansion shell rock bolt support by using the pads made of pine wood, conveyor belt, and cast rubber. The use of a deformable pad made of conveyor belt allowed a reduction in rock bolt initial stress by $5 \%$ to $10 \%$ after a single impulse, and by $20 \%$ to $25 \%$ after 10 loading cycles of vibrations. In laboratory tests, vibrations acting from the side of the load bearing pad were simulated. The torque measurements in the conditions of the exploitation workings in "Rudna" Copper Mine showed improvement of the interaction between the rock bolts with increased deformability and the rock mass. The rock bolt support with KE-3W type head (3 shells and one expander), Fig. 1, fitted with $20 \mathrm{~mm}$ thick deformable pads made of conveyor belt were used in the tests. 


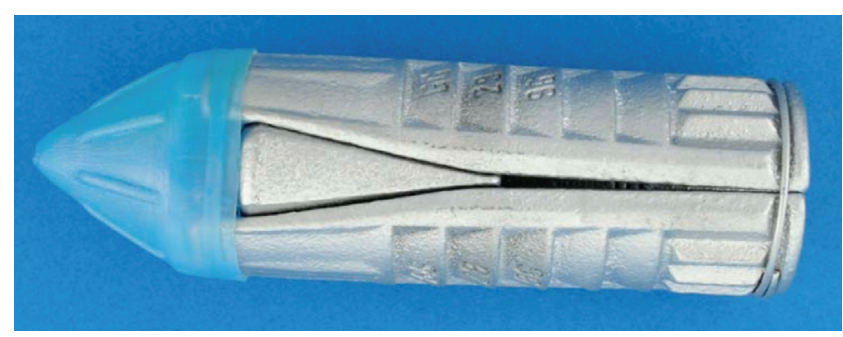

Fig. 1. KE-3W- head of the rock bolt [10]

As the depth of mining and civil underground construction increases, stress-induced rock fracturing is inevitable [15]. The occurrence of rockburst is always difficult to predict and therefore special rock support and reinforcement systems, i.e., yielding systems, must be installed after excavation to ensure total stability of the opening [26]. Most underground structures are essential to human life and include many utilizations: pipelines for water, sewage, gas, electricity and telecommunication; subways; underground roads. For these reasons it is very important to study how tunnels are damaged during earthquakes to protect human life and the service efficiency [7], [20], [38]. Many deep civil tunnels in Switzerland, China, and Peru have experienced rockbursts to various degrees. Two recent civil projects that experienced severe rockburst damage are the Jinping II hydropower intake tunnels in China [40], [43] and the Olmos TransAndean tunnel in Peru [41].

The initial stress within the bolt was reduced by $20 \%-30 \%$, as compared to the rock bolts without deformable component [33]. Current rock bolts are provided with bolt rods with specially designed variable longitudinal geometry in order to achieve increased deformability under variable loads. A number of researchers across the world have developed various original constructions such as: "Durabar" rock bolt [31], "D" [6], [22], [21] modified "Cone-bolt"
[4], [37], "NMX" [13] "DAP" [28], "Yield-Lok" [42], "Dynatork" [30]. A cylinder can be attached to the bolt rod as a deformable rock bolt support component. The cylinder is located between the washer and the rock bolt nut [12], [23]. Deformability of the rock bolt support can also be increased by the use of an internal absorber on the bolt rod, such as in the "Roofex" rock bolt [5], "Garford" [11], and "He" [9], [39].

There are a number of factors related to natural hazards (rock bursting, rock mass tremors, relaxations), local instability (roof rock falls, rock slides, development of rock mass separation), mining technological factors (blasting with explosives, mining method, and support types ), and geological factors (depth of the orebody, structure of the roof, rock strength parameters, faults) [2], [17], [24], [29]. As a result of a combination of individual factors, the roof of underground excavations sags. To increase factor of safety of the rocks forming the direct roof of the working, it is possible to use the rock bolts with increased deformability (Fig. 2). The rock bolts of this type can strengthen the working by reducing the deformation gradient of the rock mass surface located close to the rock bolt washer to an acceptable level of roof sagging [3].

\section{LABORATORY TESTS OF THE EXPANSION SHELL ROCK BOLT SUPPORT}

Expansion shell rock bolt support static tests with increased yield were conducted at the Department of Underground Mining, the AGH University of Science and Technology, Cracow, in a specially designed rig for the testing of rock bolt support tensile strength,

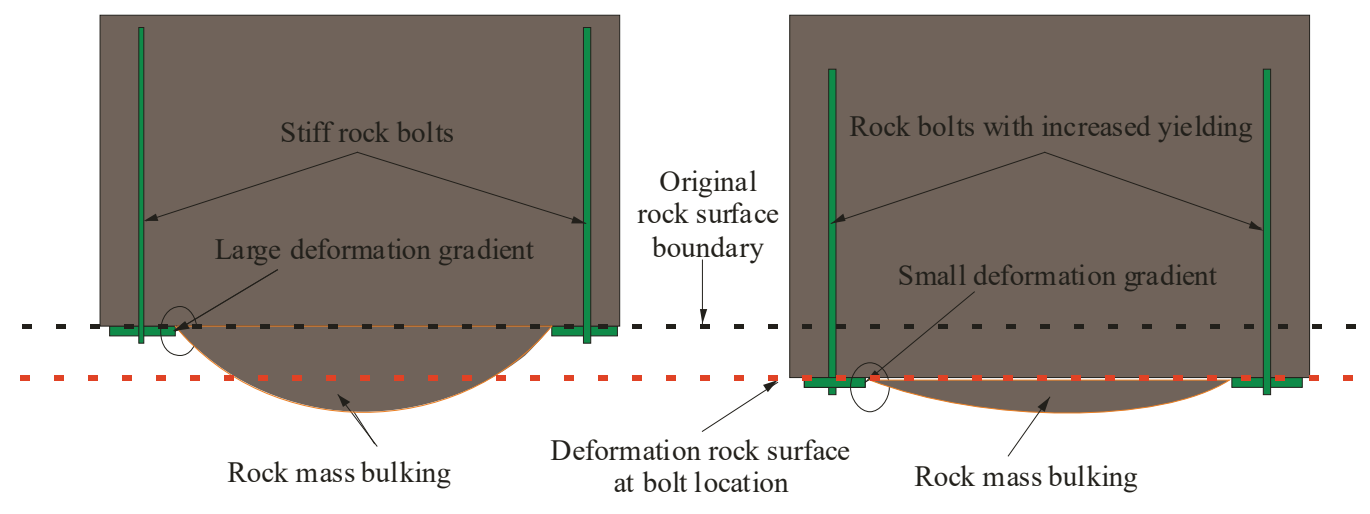

(a)

(b)

Fig. 2. The sag of the roof with the rock bolt support;

(a) without increased deformability, (b) with increased deformability (based on [3]) 


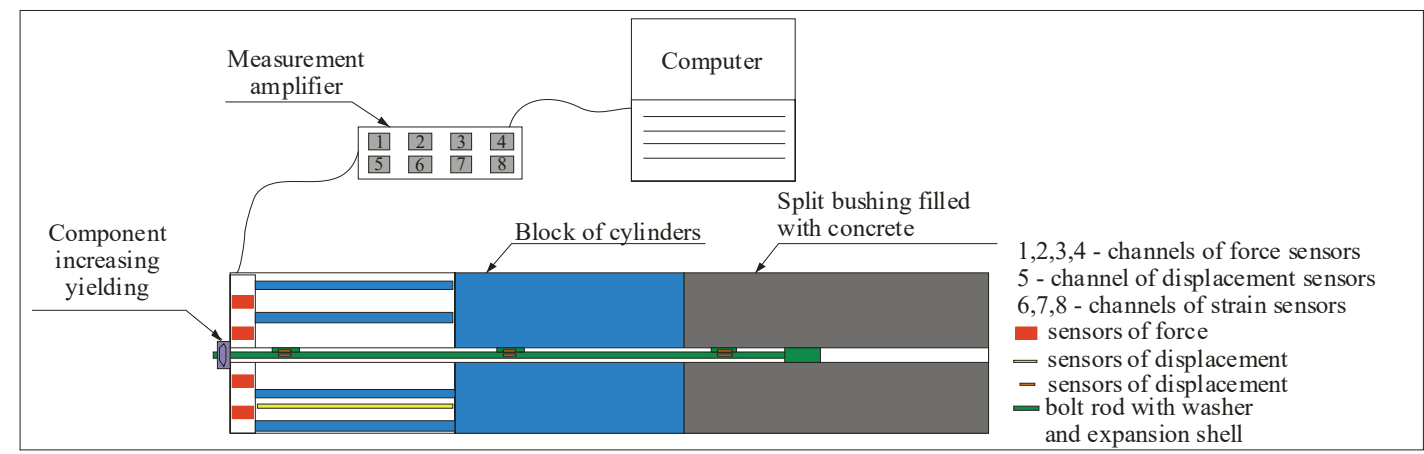

Fig. 3. Block diagram of the hydraulic system loading the rock bolt

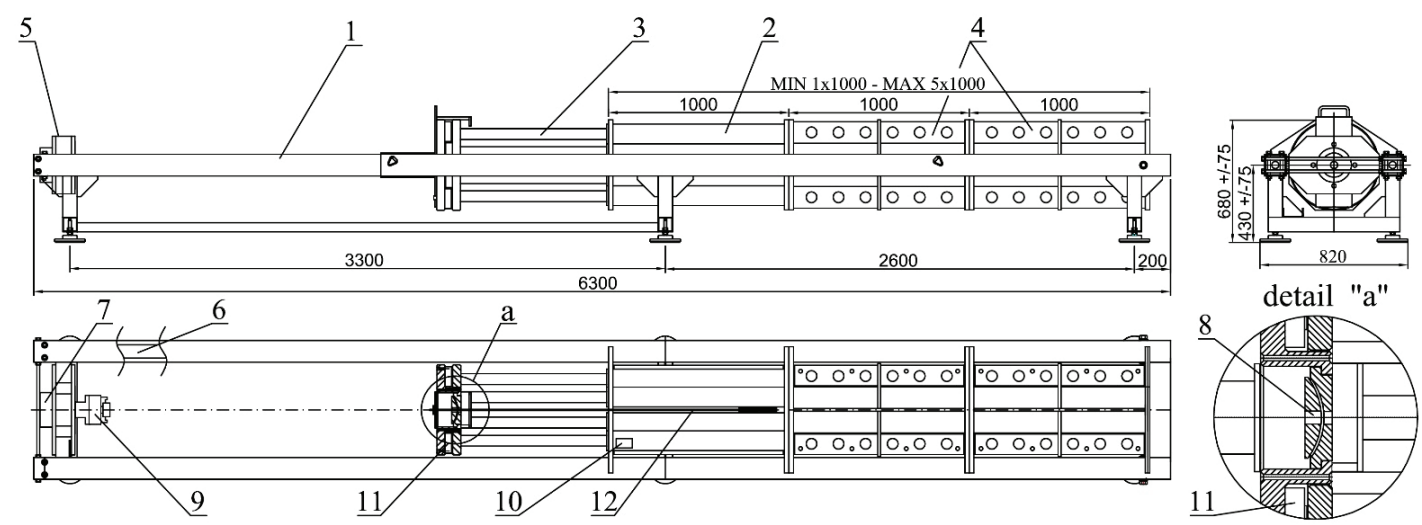

Fig. 4. Test rig for rock bolt loading tests; 1 - 11 support; 2 - block with hydraulic jacks; 3 - hydraulic jack; 4 - bushings; 5 - engine's traverse; 6 - hydraulic jack; 7 - engine; 8 - washer; 9 - triple shank; 10 - displacement sensor;

11 - force sensors; 12 - rock bolt

Fig. 3. The test rig allows 1:1 scale rock bolt testing, bolts fitted with up to $6 \mathrm{~m}$ long rods, using different methods of fixing (with expansion shells, wedges, cement, resin injections or cartridges) in the rock mass. Additionally, in a rig simulating mine conditions, particularly in KGHM Polska Miedź S.A. underground copper mines, it is possible to test the rock bolt supports at variable loads and programs, and also to set three load ranges: $400 \mathrm{kN}, 800 \mathrm{kN}$, and 1,600 $\mathrm{kN}$. The detailed description of the test rig is presented in paper [18] and in Fig. 4. Three electric resistant strain gauges, Fig 5, with temperature compensation elements, Fig. 6, were glued on the smooth surface of each rod tested, located as shown in Fig. 7. The purpose of the tests was to obtain the stress-strain characteristics of the rock bolt with increased yield and to make a comparison with the rock bolt support without increased yield.

To simulate mine conditions in the laboratory test rig, split bushes were used, Fig. 8, which were filled with concrete of uniaxial compressive strength of at least $80 \mathrm{MPa}$. Holes with diameters from 37 to $38 \mathrm{~mm}$ were made in cylindrical concrete blocks, $220 \mathrm{~mm}$ in diameter. The axially arranged holes were of the same diameter as the holes made in mining excavations.

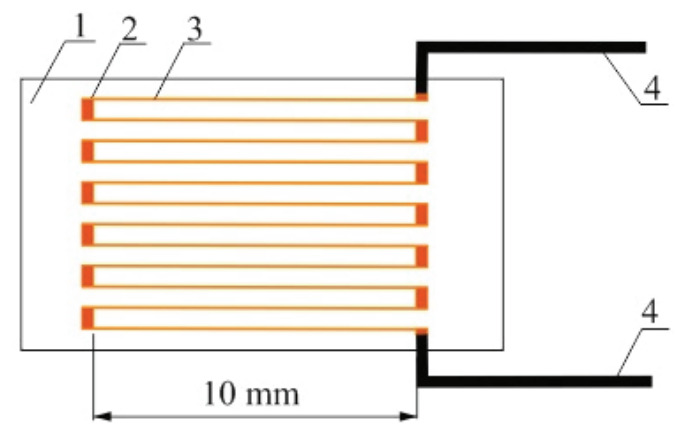

Fig. 5. Electrical resistant strain gauge; 1 - bed, 2 - borders of measurement base, 3 - resistant wire, 4 - power wires

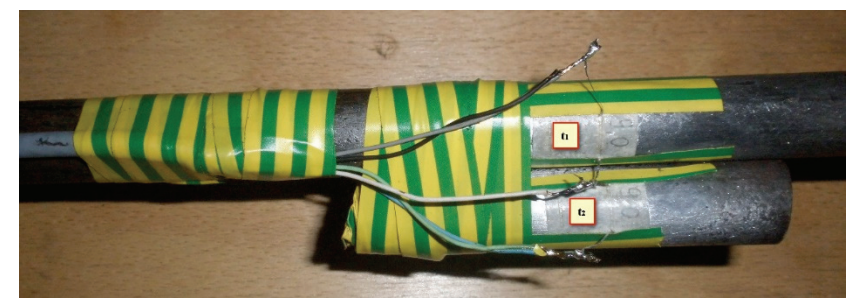

Fig. 6. Temperature compensation element 


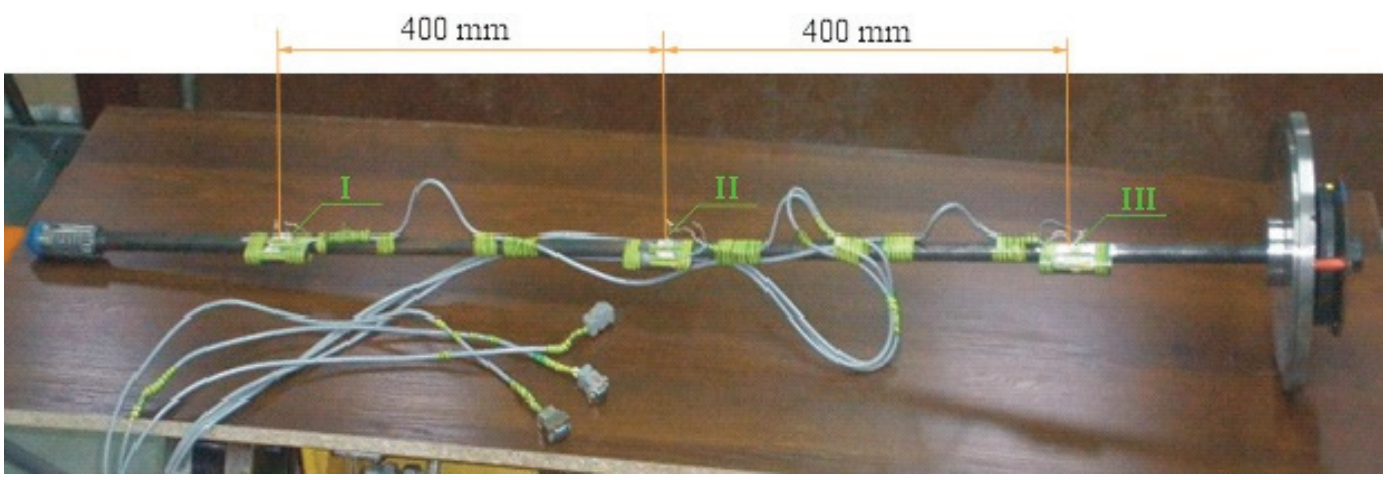

Fig. 7. View of the rock bolt instrumented with resistant strain gauges I, II, III - positions of the gauges

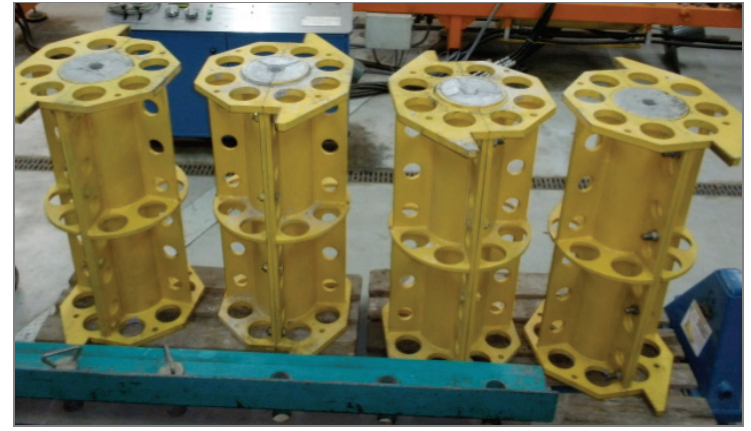

Fig. 8. Split bushings filled with concrete tionally, a deformable component, Fig. 11 a, b, was used in the tests, which consisted of two profiled rock bolt washers, two disk springs, Table 1, Fig. 12, and three mounting bolts. The disk spring and disk washer material differed in stiffness. The construction materials ensure that under loading the springs are initially partially compressed, and then the rock bolt washer is plastically deformed. Plastic deformation of the rock bolt washer is possible owing to the difference in diameters of the holes in the rock bolt washer $(22 \mathrm{~mm})$ and the disk springs $(61 \mathrm{~mm})$.

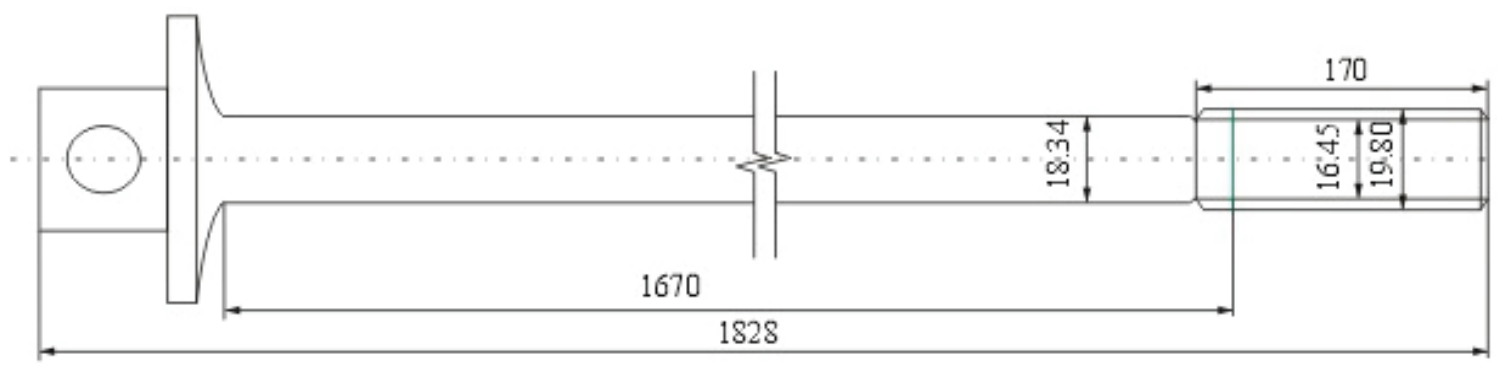

Fig. 9. Bolt rod - RS-2N type

The expansion shell rock bolts used in the tests constitute the basic reinforcement method for exploitation workings in Polish copper mines. The rock bolt support consists of the bolt rod of RS-2N type, length $(l)$ from $1,823 \mathrm{~mm}$ to $1,834 \mathrm{~mm}$ and diameter $(d)$ from $18.24 \mathrm{~mm}$ to $18.29 \mathrm{~mm}$, Fig. 9 .

One end of the bolt rod had a cold rolled thread M20, whereas the other end had a square profile adapted to give a torque (to rotate the rod). The bolt rod works together with the KE3-2K type expansion shell head, Fig. 10, length $136 \mathrm{~mm}$ and diameter $36 \mathrm{~mm}$. The head consists of three shells, two expanders, $31 \mathrm{~mm}$ diameter spring, and a conical cap.

The $6 \mathrm{~mm}$ thick, profiled round rock bolt washers were used in the tests. This shape of washer was selected due to its popularity in the ore mining involving the use of expansion shell rock bolt support. Addi-

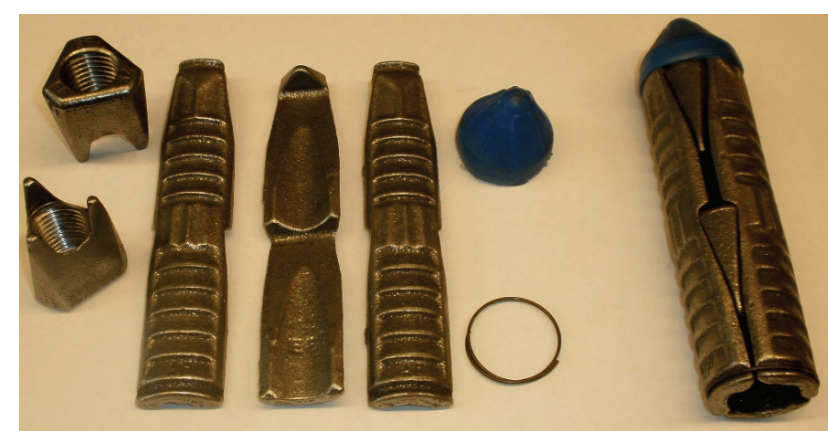

Fig. 10. KE3-2K- head of the expansion rock bolt

The improvement of rock bolt deformability involved the use of an additional component, Fig. 11a, $\mathrm{b}$, c, on the bolt rod applied from the excavation side. In the laboratory, the increment of load reduced the height of the deformable component. During the time 
(a)

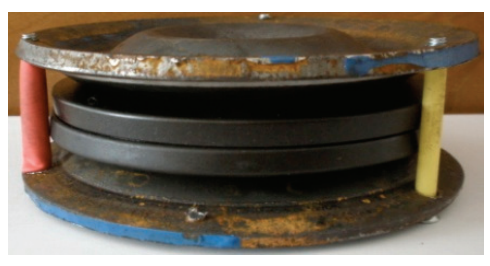

(b)

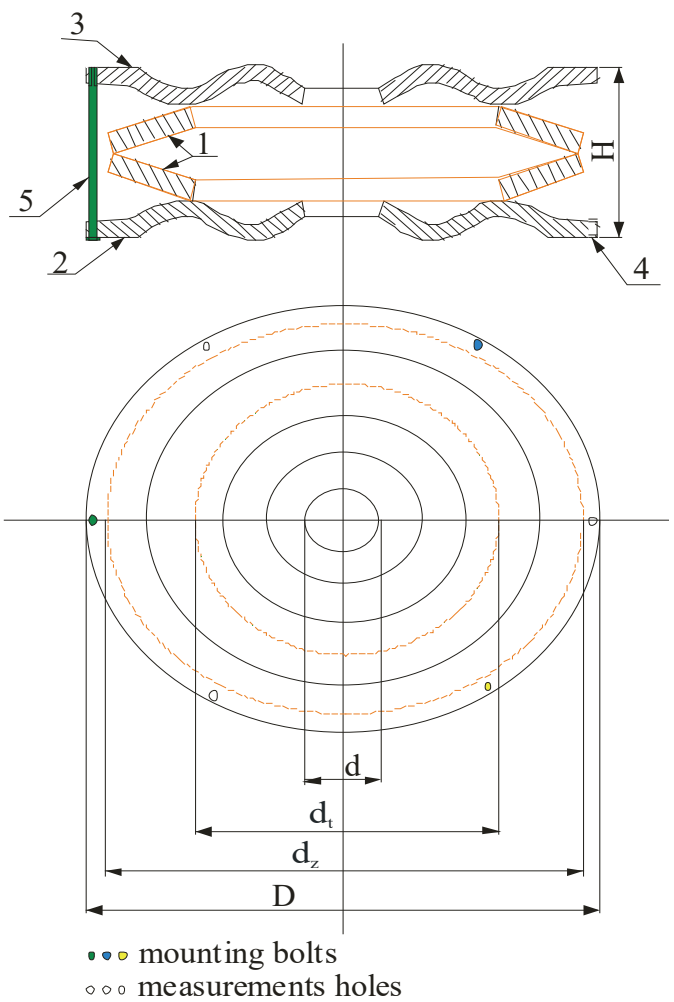

(c)

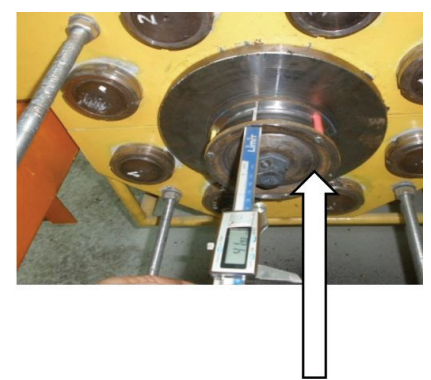

the component set up on the stand

Fig. 11. The deformable component: (a) general view, (b) vertical cross-section, (c) on the test rig during measurements (by means of calliper), $d$ - internal diameter $(22 \mathrm{~mm}), d_{t}$ - internal diameter of the disk spring $(125 \mathrm{~mm})$, $D$ - external diameter of the component ( $141 \mathrm{~mm}), H$ - height of the component $(55 \mathrm{~mm}), 1$ - disk springs, 2,3 - standard rock bolt washers, 4 - measurement hole, 5 - guide bar

Table 1. Technical specification of the disk spring, Fig. 12

\begin{tabular}{|l|c|}
\hline \multicolumn{1}{|c|}{ Parameter } & Characteristics \\
\hline External diameter $d_{z}, \mathrm{~mm}$ & 125 \\
\hline Internal diameter $d_{t}, \mathrm{~mm}$ & 61 \\
\hline Material thickness $t, \mathrm{~mm}$ & 8 \\
\hline Free height of the unloaded spring $H, \mathrm{~mm}$ & 10.90 \\
\hline Free height of the unloaded spring cone $h, \mathrm{~mm}$ & 2.90 \\
\hline Force $(0.75 \mathrm{~h}), \mathrm{kN}$ & 93.600 \\
\hline Material & $50 \mathrm{CrV} 4$ \\
\hline
\end{tabular}

(a)

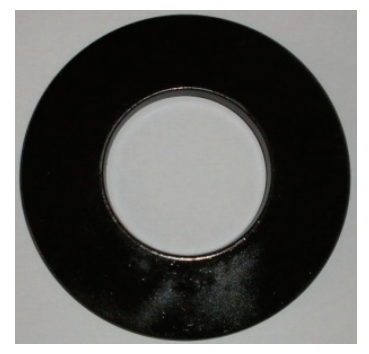

b)

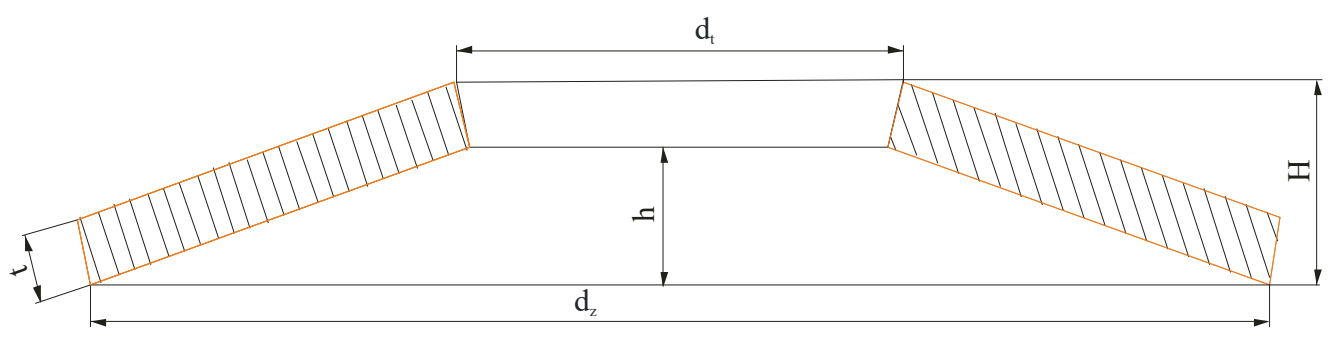

Fig. 12. Disk spring: (a) top view, (b) spring dimensions

between successive pressure build-ups, the height was measured with an electronic calliper with reading accuracy of $\pm 0.01 \mathrm{~mm}$, using the calliper depth gauge through the three holes spaced every 120 degrees in the rock bolt washer. This measurement was also used to calibrate the component. Calibration consisted of 
the determination of height change in the component with increasing load. The force $F$ was recorded in the Catman Easy application, whereas the height change in the component, $\Delta h$, was determined using an electronic calliper in three measurement points, Fig. $11 \mathrm{c}$. The measurement of reduction of the height of the component up to the end of elastic range was carried out on the basis of loading-displacement characteristics of the rock bolt at static load without any increase in deformability. This resulted from the need to maintain safety conditions at the test rig. When the bolt rod breaks, the elements of the rock support are thrown out with some of the kinetic energy. As a result, after exceeding the elastic limit of the bolt rod some protective cylinders were used, making further measurements impossible.

The increase of the rock bolt support deformability during testing involves taking advantage of the incomplete compression of the disk springs, and plastic strain of the rock bolt washer at the side of the bolt rod head, Figs. 13, 14b. As a result of differences in concrete block. Using a dynamometric wrench, the head was expanded within the hole, applying a torque of $250 \mathrm{Nm}$ (in accordance with the requirements for rock bolts used in mines). After expanding the head in the hole, preliminary tension of $30 \mathrm{kN}$ was applied with hydraulic jacks in the test rig. The static tension tests involved a temporary increase of pressure by 10 bar. This was set by the hand wheel of the pressure reducing valve in the test rig. Each increase of pressure was preceded by a loading time of $10 \mathrm{~s}$. The average test duration until rupture was $120 \mathrm{~s}$, matching both the requirements posed by the Polish standards [32] for the tension tests, and the conditions corresponding to the static load increment in underground chamber workings. During the whole loading cycle, the tensile force was measured continuously by four KKM 50 type force sensors installed on a slidable disk of the hydraulic device (HUK). The bolt rod strain value was also recorded by means of three electric resistance wire strain

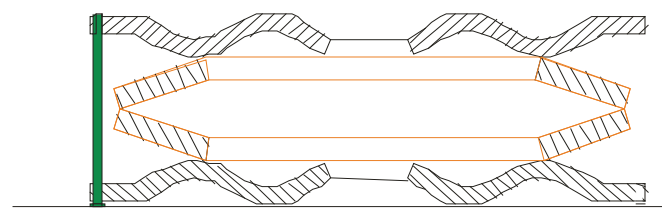

(a)

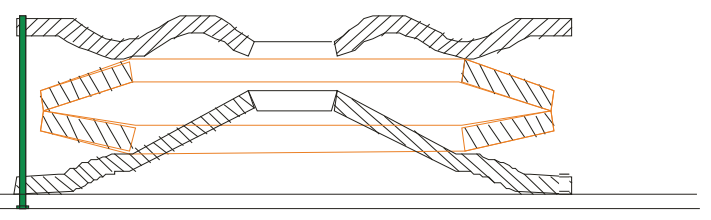

(b)

Fig. 13. Behavior of the deformable component: (a) before test, (b) after test

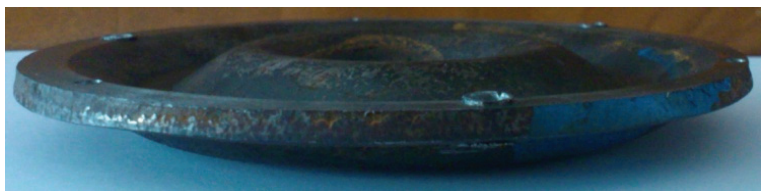

(a)

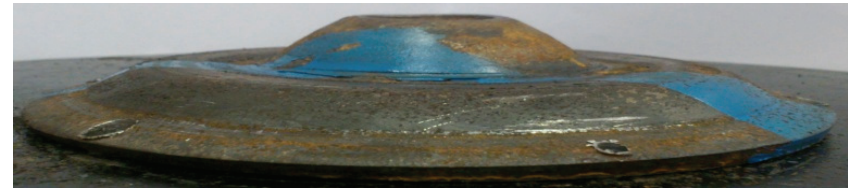

(b)

Fig. 14. The rock bolt washer used in the deformable component: (a) before test, (b), after test

the diameters of the rock bolt washer and the disk springs, there is a possibility of plastic deformation towards the internal diameter of the disk springs along the bolt rod axis. This means that the total displacement will be greater compared to the rock bolt support without increased deformability.

\section{MECHANISM OF STATIC TENSION OF EXPANSION SHELL ROCK BOLT WITH THE YIELDED COMPONENT}

The rock bolt with sensors and the deformable component were manually inserted into a hole in the gauges glued onto its cylindrical part at equal distances of $400 \mathrm{~mm}$ from each other. Additionally, the test rig was equipped with one draw wire encoder recording total elongation until rupture. The individual sensors of force, displacement and strain were connected to the universal measurement amplifier QuantumX MX840. During the entire static tension process, data from individual sensors were recorded using Catman Easy, an application suitable for such purposes. As a result of using the deformable component, a modified stress-strain characteristic of the rock bolt support was obtained. The examples of characteristic parameters obtained during the tests are shown in Tables 2 and 3, and in Figs. 17-25 and 36-38. 
Table 2. Technical specification of the rock bolt support with the deformable component under static tension

\begin{tabular}{|c|c|c|c|c|}
\hline No. & \multicolumn{2}{|l|}{ Parameter } & Unit & Value \\
\hline 1 & \multicolumn{2}{|l|}{ Bolt rod length, $l$} & $\mathrm{~mm}$ & 1.828 \\
\hline 2 & \multicolumn{2}{|l|}{ Active length of bolt rod, $l_{0}$} & $\mathrm{~mm}$ & 1.670 \\
\hline 3 & \multicolumn{2}{|l|}{ Diameter of bolt rod, $d$} & $\mathrm{~mm}$ & 18.34 \\
\hline 4 & \multicolumn{2}{|l|}{ Diameter of bolt rod, $d_{3}$} & $\mathrm{~mm}$ & 16.45 \\
\hline 5 & \multicolumn{2}{|l|}{ Breaking force, $F$} & $\mathrm{kN}$ & 167.030 \\
\hline 6 & \multicolumn{2}{|l|}{ Displacement, $\Delta l$} & $\mathrm{~mm}$ & 136.161 \\
\hline 7 & \multicolumn{2}{|l|}{ Tension time until the rod rupture, $t$} & $\mathrm{~s}$ & 104.80 \\
\hline 8 & \multicolumn{2}{|l|}{ Loading rate, $v$} & $\mathrm{~m} / \mathrm{s}$ & 0.00130 \\
\hline 9 & \multicolumn{2}{|l|}{ Maximum tensile stress, $\sigma_{r}$} & MPa & 785.911 \\
\hline 10 & \multicolumn{2}{|l|}{ Relative strain, $\varepsilon$} & $\%$ & 8.513 \\
\hline \multirow{2}{*}{11} & \multirow{2}{*}{$\begin{array}{l}\text { Force corresponding to the strain of electric resistance wire } \\
\text { strain gauge } \varepsilon 1, \varepsilon 2, \varepsilon 3 \text {, at the level of } 2 \%, F_{s}\end{array}$} & $F_{s 1}$ & \multirow{2}{*}{$\mathrm{kN}$} & 100.016 \\
\hline & & $F_{s 2}=F_{s 3}$ & & 105.042 \\
\hline \multirow{2}{*}{12} & \multirow{2}{*}{$\begin{array}{l}\text { Displacement corresponding to the strain of electric resis- } \\
\text { tance wire strain gauge } \varepsilon 1, \varepsilon 2, \varepsilon 3 \text {, at the level of } 2 \%, \Delta l\end{array}$} & $\Delta l_{1}$ & \multirow{2}{*}{$\mathrm{mm}$} & 8.886 \\
\hline & & $\Delta l_{2}=\Delta l_{3}$ & & 10.840 \\
\hline \multirow{2}{*}{13} & \multirow{2}{*}{ Tension time in the elastic range $t_{s}$} & $t_{s 1}$ & \multirow{2}{*}{$\mathrm{s}$} & 55.95 \\
\hline & & $t_{s 2}=t_{s 3}$ & & 57.98 \\
\hline \multirow{2}{*}{14} & \multirow{2}{*}{ Elastic range of the deformable component, $\psi^{*}$} & $F_{s t}$ & $\mathrm{kN}$ & 88 \\
\hline & & $\Delta h$ & $\mathrm{~mm}$ & 0.99 \\
\hline
\end{tabular}

* The elastic range of the deformable component, $\psi^{*}$ is the range, where an incomplete compression of disk springs occurs, and after relieving, the spring returns to its initial position. After exceeding this range, the rock bolt washer of the deformable component at the side of the rod flange undergoes deformation towards the internal hole of the disk springs (Figs. 13, 14). The values of force $F_{s t}$ and reduction in sensor height are specified for this range.

The diagram of loading for the rock bolt support installed in the concrete block 1 using the expansion shell head 2 placed on the rod 3 on one side and the deformable component $\mathrm{Eu} 4$ on the other side, effected by piston 5 and force $F$, is shown in Fig. 15. The following symbols are used in the analysis:

$F$ - force loading the rock bolt, $[\mathrm{kN}]$,

$\Delta L g 1$ - the head displacement in the hole, Phase I, [mm],

$\Delta L g 2$ - the head displacement in the hole, Phase II, [mm],

$\Delta L p$ - the displacement of the deformable component $\mathrm{Eu}$ (washers), [mm],

$\Delta L z$ - the displacement of bolt rod, [mm],

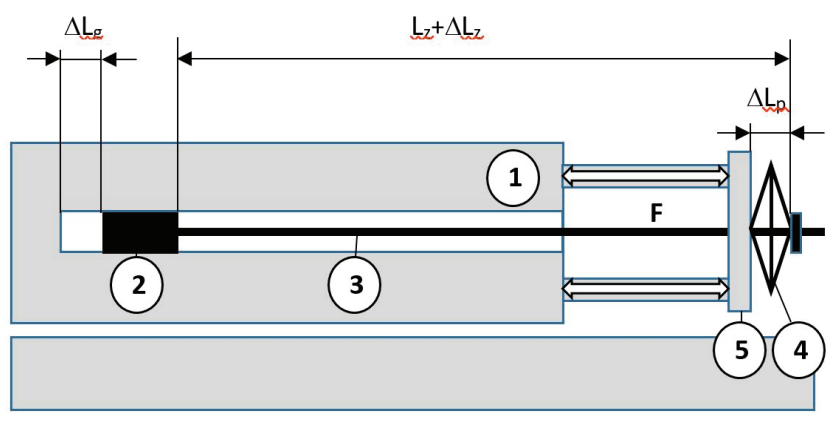

Fig. 15. Diagram showing model of the rock bolt installed and loaded at the test rig; 1 - concrete block; 2 - bolt head;

3 - bolt rod; 4 - deformable component; 5 - piston
$\Delta M$ - the sum of the displacements of the rock bolt with head and deformable component [mm].

As a consequence of the action of the force $F$ along the bolt rod with $L z$ length, it lengthens by $\Delta L z$ and the head is displaced as it slides in the hole by $\Delta L g$. This is followed by the displacement due to the shortening of the Eu element by $\Delta L p$. The sum of those displacements is shown as $\Delta M$,

$$
\Delta M=\Delta L g+\Delta L z+\Delta L p .
$$

Along with the progressive elongation and/or displacement of the head and the rod, the deformable component 4 is being compressed by $\Delta L p$. Assuming the elasticity of strains within the range of the linear parts of the characteristics in the loadstrain system, it is possible to define the following relationships describing the stiffness of the following components $\left(k_{i}-\right.$ the stiffness understood as the ratio of the acting force and the displacement incurred):

Stiffness of the rock bolt interacting with the head (phase I), $\mathrm{kN} / \mathrm{mm}$

$$
k_{g z 1}=\frac{F}{\Delta M 1} .
$$

Stiffness of the rock bolt interacting with the head (phase II), $\mathrm{kN} / \mathrm{mm}$ 


$$
k_{g z 2}=\frac{F}{\Delta M 2} .
$$

Stiffness of the deformable component, $\mathrm{kN} / \mathrm{mm}$

$$
k_{p}=\frac{F}{\Delta L_{p}} .
$$

Stiffness of the rod, $\mathrm{kN} / \mathrm{mm}$

$$
k_{z}=\frac{F}{\Delta L_{z}} .
$$

The stiffness $k$ of the system (head-bolt $\operatorname{rod}-E u$ ) under loading with the force $\mathbf{F}$ can be defined with the formula

$$
\begin{gathered}
k=\frac{F}{\Delta M 1}=\frac{F}{\Delta L p+\Delta L z+\Delta L g 1} \\
=\frac{F}{F\left(\frac{1}{k p}+\frac{1}{k z}+\frac{1}{k g 1}\right)}=\frac{1}{\frac{1}{k p}+\frac{1}{k z}+\frac{1}{k g 1}} .
\end{gathered}
$$

After reduction we have

$$
k=\frac{k p \cdot k z \cdot k g 1}{k z \cdot k g 1+k p \cdot k g 1+k p \cdot k z} .
$$

According to the methodology of test measurements, it is possible to read adequate stiffness values ( $k p$ and $k z$ ) on the basis of measured values of the Eu element, strains $\Delta L p$ and the longitudinal strains $\Delta L z$ of the bolt rod (phase I) from the chart shown in Fig. 17 and the formulas referred to above. The measurement of the displacements carried out using the encoder takes into account the sum of displacements and it does not provide the possibility to directly determine head displacement $\Delta L g 1$ and its stiffness $\mathrm{kg} 1$. The F-G section of the characteristic allows determining the stiffness

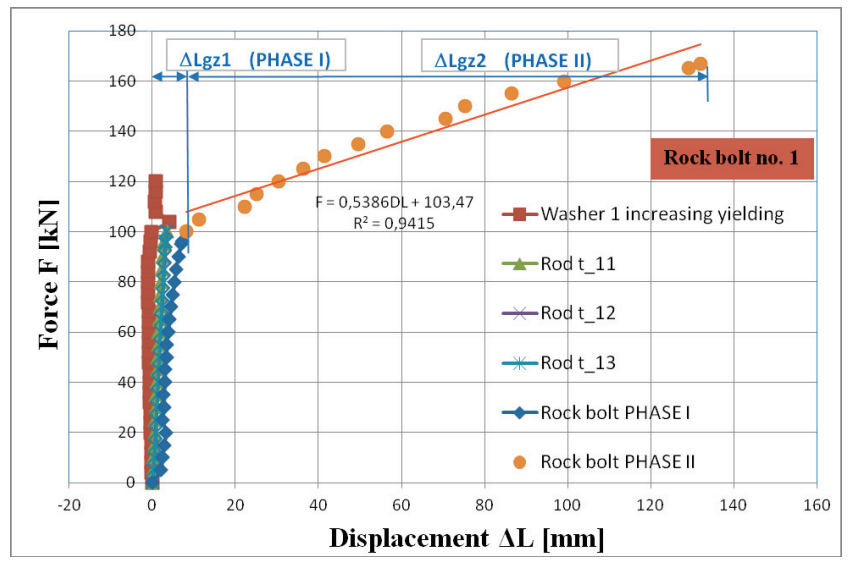

Fig. 16. The full loading characteristics for the rock bolt No. 1 with the deformable component

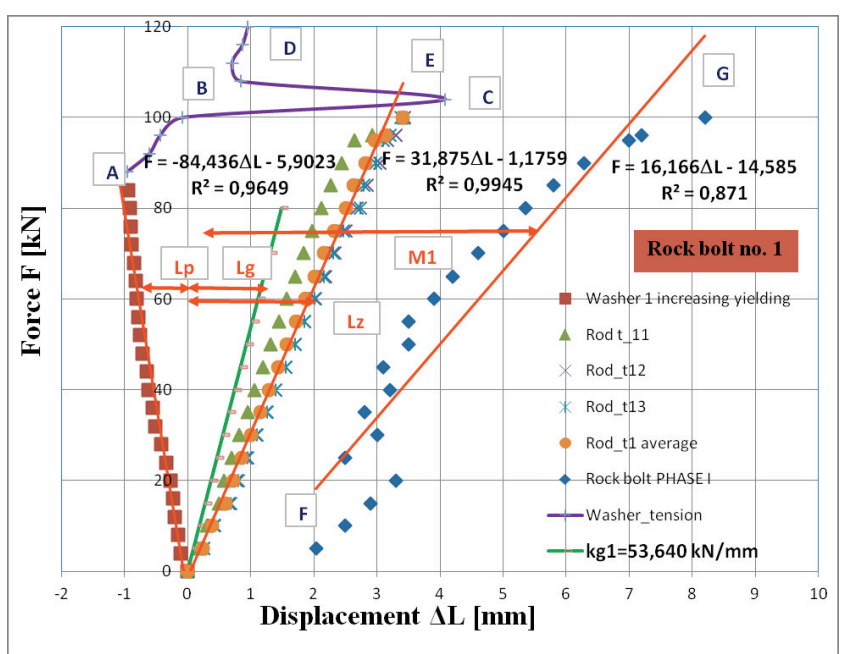

Fig. 17. The detailed loading characteristics for the components of the rock bolt support No. 1

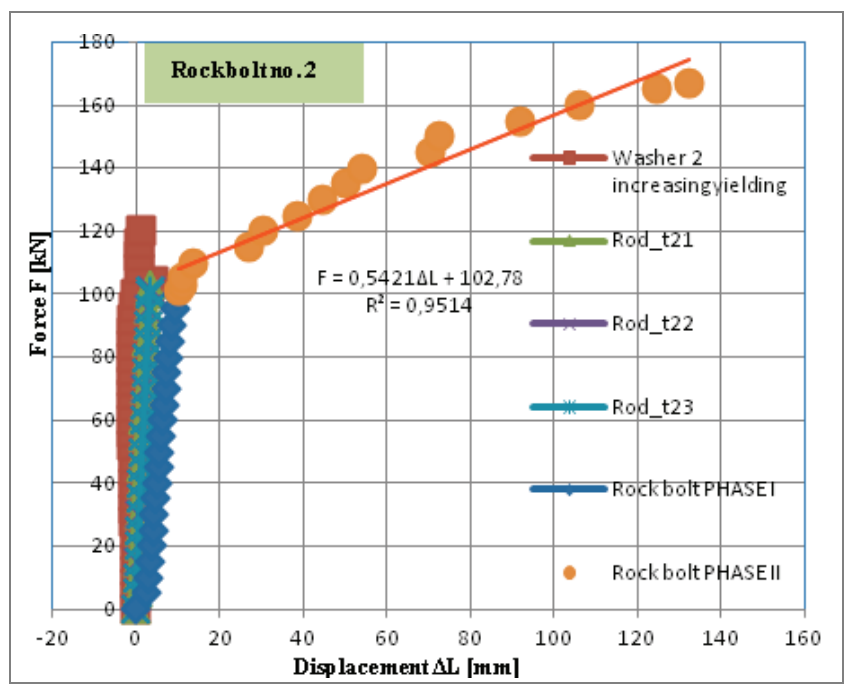

Fig. 18. The full loading characteristics for bolt No. 2 with the deformable component

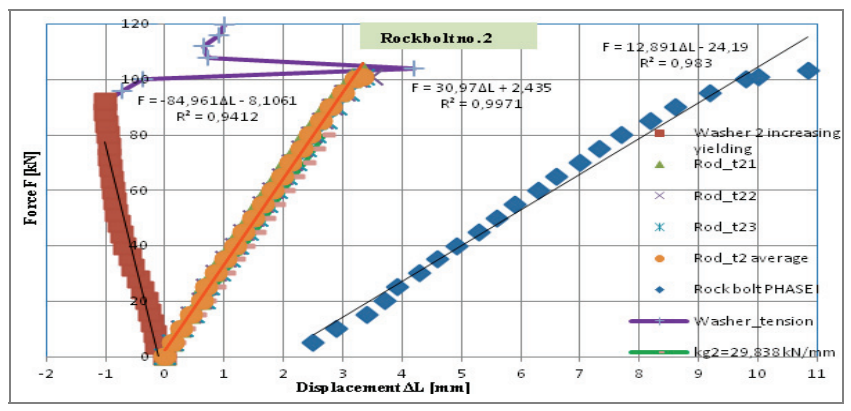

Fig. 19. The detailed loading characteristics for the components of the rock bolt support No. 2

of the whole system $k$ (rod-head-Eu element) only. However, taking into consideration the relationship (7), it is possible to determine indirectly the stiffness $k g 1$ of the head itself only. Proper values are given in the charts, Figs. 17, 19, 21, 23, 25. The slopes of the 
straight lines are interpreted as the indicators of proper stiffness values of components.

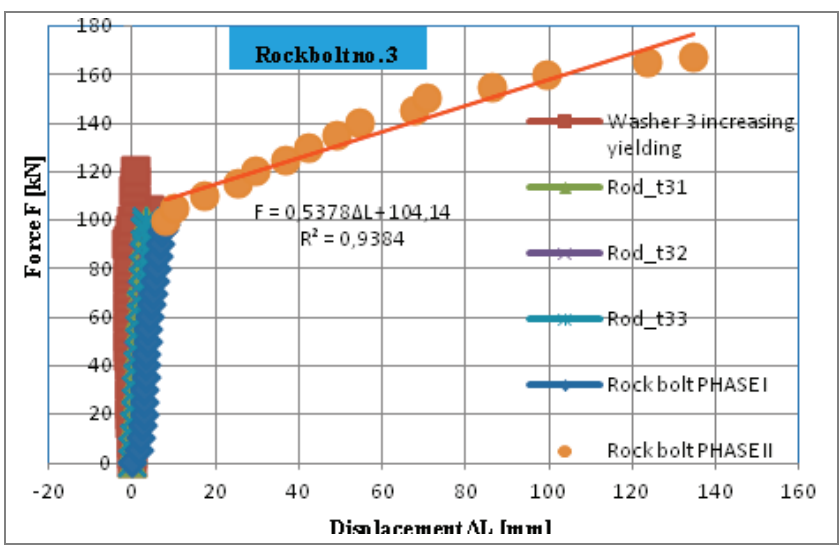

Fig. 20. The full loading characteristics for bolt No. 3 with the deformable component

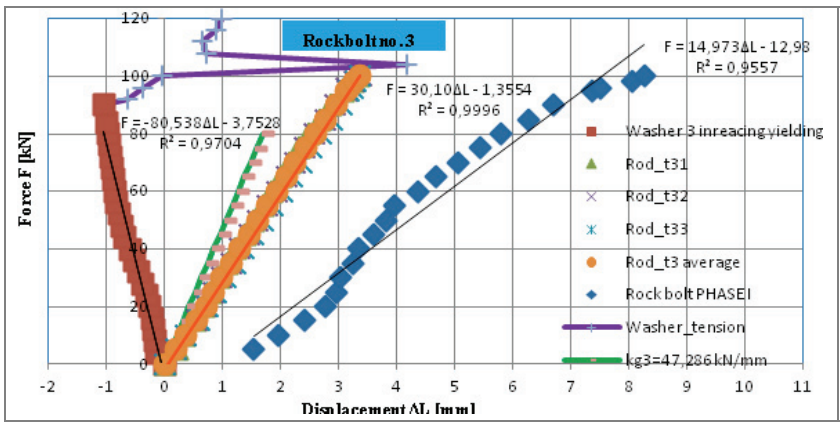

Fig. 21. The detailed loading characteristics for the components of the rock bolt support No. 3

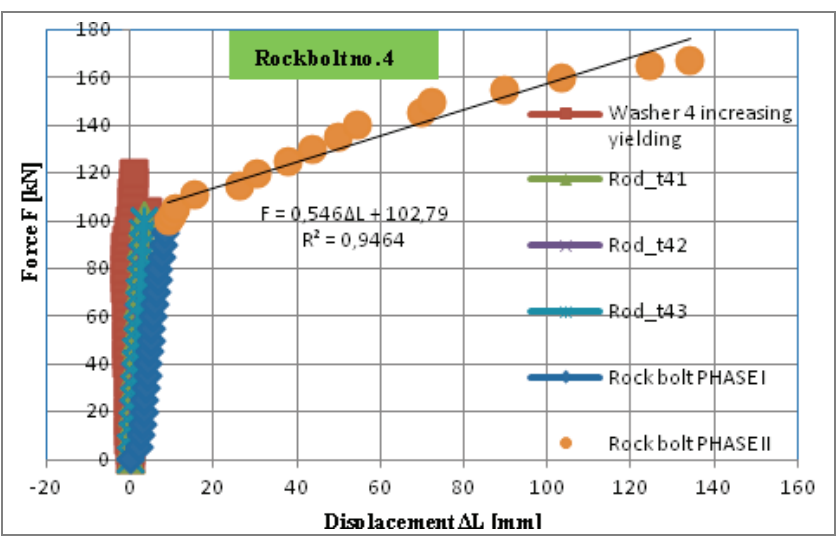

Fig. 22. The full loading characteristics for bolt No. 4 with the deformable component

The values applied in further analysis of the process involving the rock bolt support loading on the test rig are marked and explained in Figs. 16 and 17. In Fig. 16, two displacement ranges are distinguished. The $\Delta L g z 1$ range corresponds to the intensive displacements of the head and the bolt rod (Phase I loading), altogether not exceeding $10 \mathrm{~mm}$. Further loading, marked as $\Delta L g z 2$, is Phase II loading characterised by the displacements of up to ca. $140 \mathrm{~mm}$. For the characteristic section within the range of the $\Delta \operatorname{Lgz} 2$ displacements, a linear approximation was carried out, and the appropriate equations for the course of variability of the force $F$ loading the rock bolt versus $\Delta L$ displacements were formulated. Analogical symbols and equations are shown in Figs. 18, 20, 22, 24 with reference to successive experiments carried out and rock bolts.

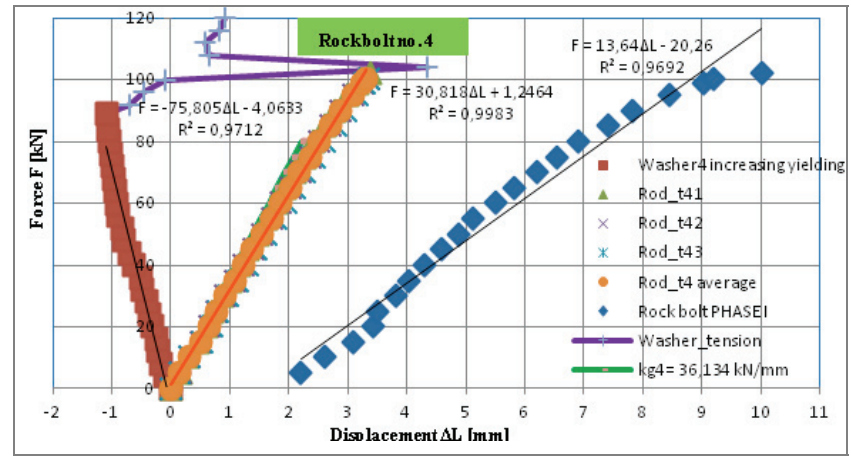

Fig. 23. The detailed loading characteristics for the components of the rock bolt support No. 4

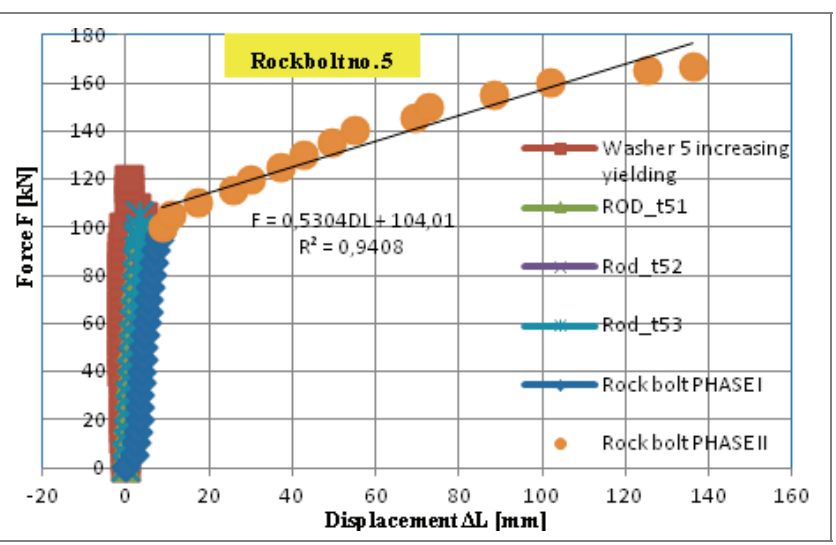

Fig. 24. The full loading characteristics for bolt No. 4 with the deformable component

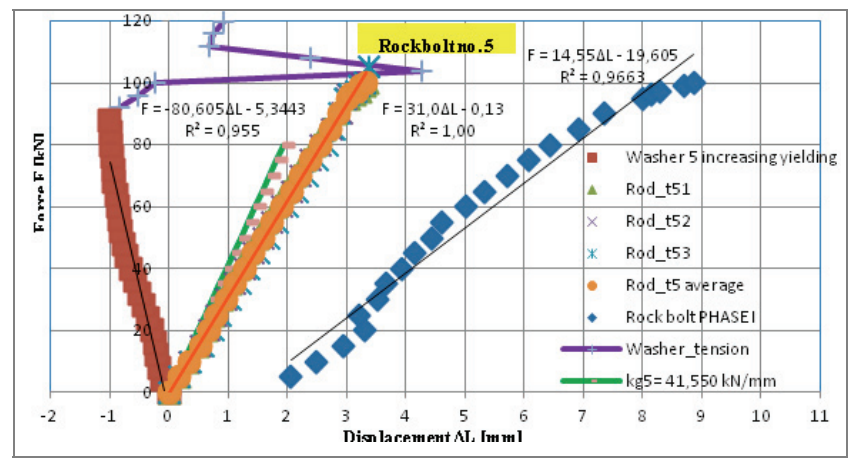

Fig. 25. The detailed loading characteristics for the components of the rock bolt support No. 5 
Table 3. The stiffness of the components of the rock bolt support and the rock bolt with increased deformability as a system composed of those elements

\begin{tabular}{|l|c|c|c|c|c|}
\hline \multirow{2}{*}{} & \multicolumn{5}{|c|}{ Stiffness coefficients, $k[\mathrm{~N} / \mathrm{mm}]$} \\
\cline { 2 - 6 } & $k p$ & $k z$ & $k g 1$ & $\mathrm{k} 1 \mathrm{u}-$ Phase I & $\mathrm{k} 2 \mathrm{u}-$ Phase II \\
\hline Rock bolt No. 1 & 84.436 & 31.875 & 53.640 & 16.166 & 0.5386 \\
\hline Rock bolt No. 2 & 84.961 & 30.970 & 29.838 & 12.891 & 0.5421 \\
\hline Rock bolt No. 3 & 80.538 & 30.100 & 47.286 & 14.973 & 0.5378 \\
\hline Rock bolt No. 4 & 75.805 & 30.818 & 36.134 & 13.640 & 0.5460 \\
\hline Rock bolt No. 5 & 80.605 & 31.000 & 41.550 & 14.550 & 0.5304 \\
\hline Average & 81.3 & 31.0 & 41.7 & 14.4 & 0.54 \\
\hline
\end{tabular}

Table 4. The stiffness of the components of the rock bolt support and the rock bolt without increased deformability as a system composed of those elements

\begin{tabular}{|l|c|c|c|}
\hline \multirow{2}{*}{} & \multicolumn{3}{|c|}{ Stiffness coefficients, $k[\mathrm{~N} / \mathrm{mm}]$} \\
\cline { 2 - 4 } & $k z$ & $\mathrm{k} 1-$ Phase I & $\mathrm{k} 2-$ Phase II \\
\hline Rock bolt No. 1A & 37.78 & 6.15 & 0.66 \\
\hline Rock bolt No. 2A & 32.55 & 6.51 & 0.69 \\
\hline Rock bolt No. 3A & 32.56 & 7.26 & 0.64 \\
\hline Rock bolt No. 4A & 32.47 & 7.67 & 0.67 \\
\hline Rock bolt No. 5A & 32.408 & 8.14 & 0.66 \\
\hline Average & 33.5 & 7.1 & 0.66 \\
\hline
\end{tabular}

Based on Figs. 17, 19, 21, 23 and 25, it is possible to analyse in detail the relationships of the appropriate forces and displacements measured during the tests in Phase I loading. The symbols are shown in Fig. 17 to minimise the information contained in each chart. The part of the chart within coordinate range $\Delta L<0$ refers to the displacements of the deformable component. The following characteristic parts can be distinguished:

0-A The range of the elastic strains - compression of the deformable component.

A-B The range of the elastic strains - expansion (return to the initial position).

B-C-D The range of the elastic strains of the deformable component - height increment and reduction.

The linear approximation has been used to describe the linear relationship between the force and the displacements in the $0-\mathrm{A}$ range and the equation is given in the chart. The other characteristics are related to re-expanding of the deformable component $\mathrm{Eu}$, and then elastic deformation, partially irreversible. Furthermore, the chart in Fig. 17 demonstrates the course of the bolt rod strains $0-\mathrm{E}$ within range of elasticity, determined using three strain gauges (bolt $t$ 11, $t$ 12, $t$ 13). After averaging of those values (rod t1 av), a linear approximation was made and an appropriate straight line equation was formulated. The numerical values of slopes for the straight

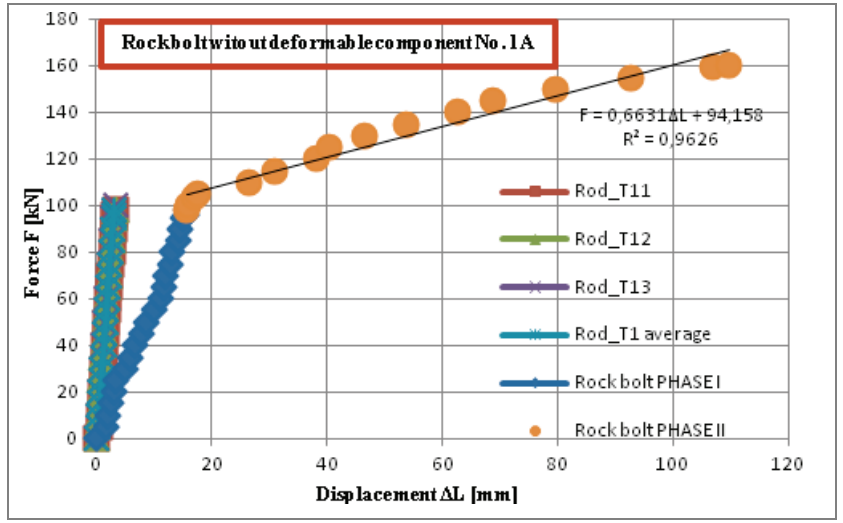

Fig. 26. Full loading characteristics for the rock bolt No. 1A

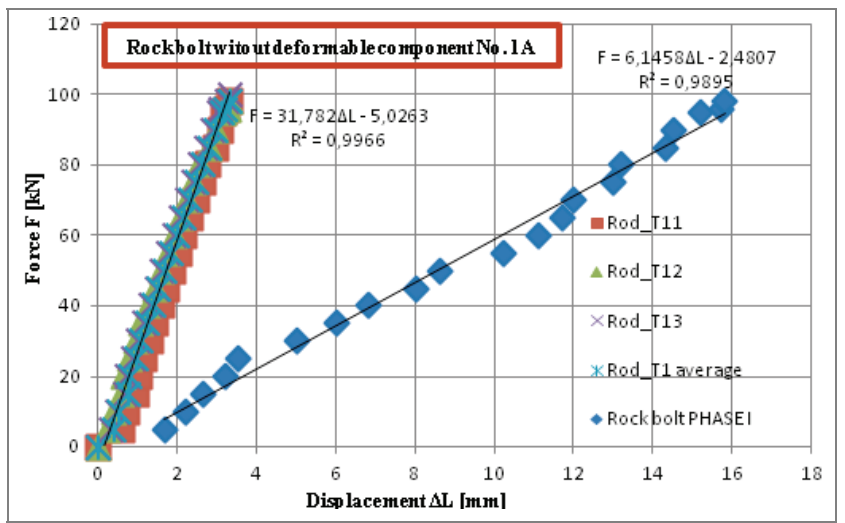

Fig. 27. Detailed loading characteristics for the components of the rock bolt support No. $1 \mathrm{~A}$ 
lines approximating the measurement results, corresponding to stiffness values defined using formulas (2)-(7), are listed in Tables 3 and 4. Additionally, Figs. 26-35 show the load-displacement characteristics of the rock bolts without the deformable component.

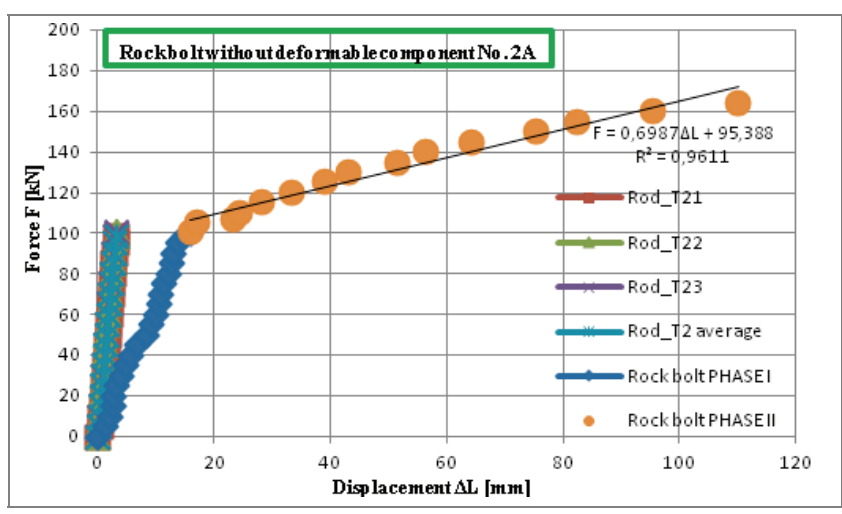

Fig. 28. Full loading characteristics for the rock bolt No. 2A

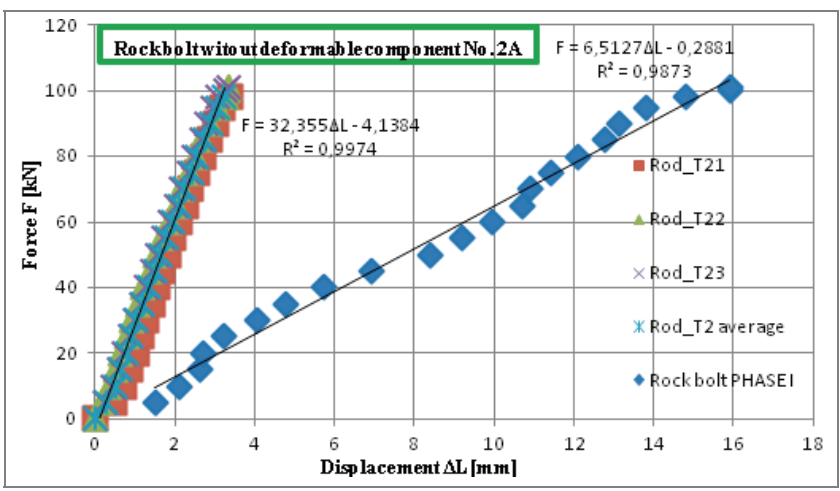

Fig. 29. Detailed loading characteristics for the components of the rock bolt support No. $2 \mathrm{~A}$

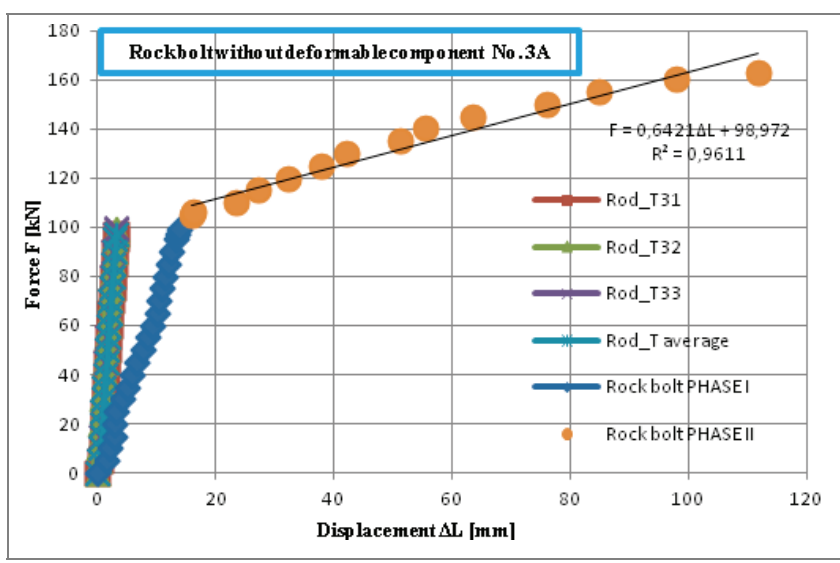

Fig. 30. Full loading characteristics for the rock bolt No. 3A

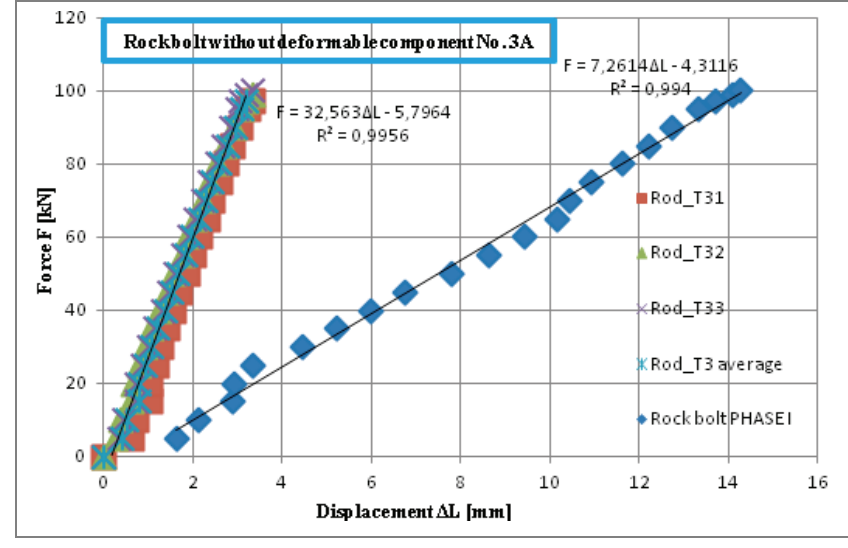

Fig. 31. Detailed loading characteristics for the components of the rock bolt support No. 3A

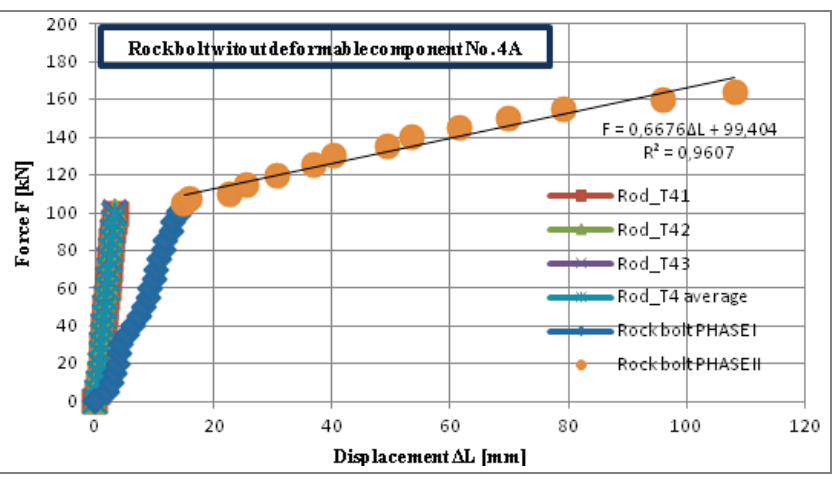

Fig. 32. Full loading characteristics for the rock bolt No. 4A

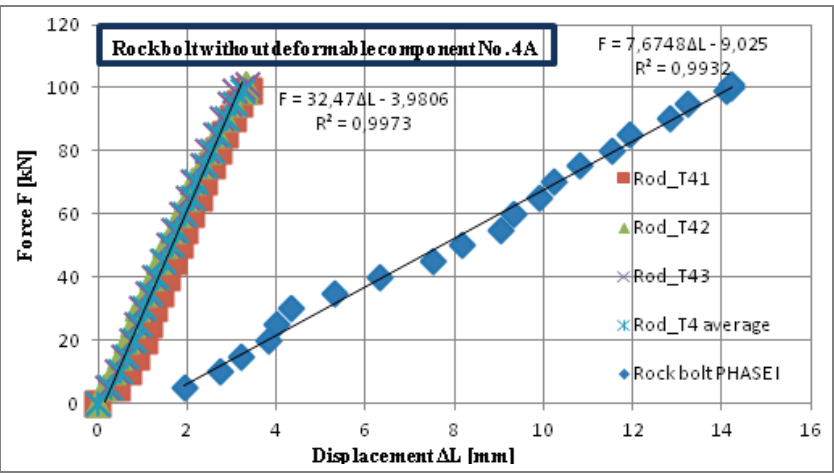

Fig. 33. Detailed loading characteristics for the components of the rock bolt support No. 4A

The $\mathrm{F}-\mathrm{G}$ section corresponds to the sum of head displacements and the bolt rod strains taking into consideration shift of the Eu component, as measured using a precise draw wire encoder. The straight line equation (rock bolt 1) was formulated as a result of the linear approximation, see Fig. 17.

Using the deformable component, as a specific rock bolt washer, brought about changes in the stiffness of the system "head-bolt-deformable component", as compared to the system without that component. The 
analyses of the measured strains (displacements) shows that as a result of the use of the deformable component, the bolt rod deformation is $8 \%$ larger than in the case of the stiff bolt (transition from A to B), see Fig. 36.

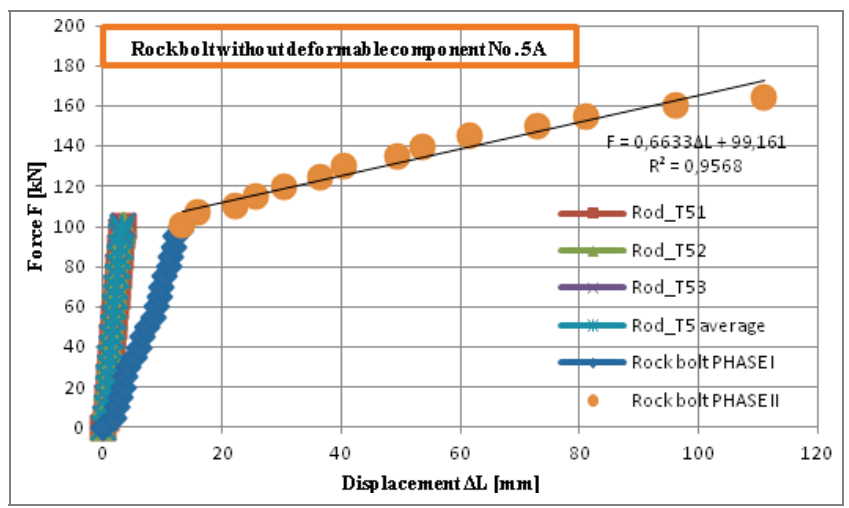

Fig. 34. Full loading characteristics for the rock bolt No. 5A

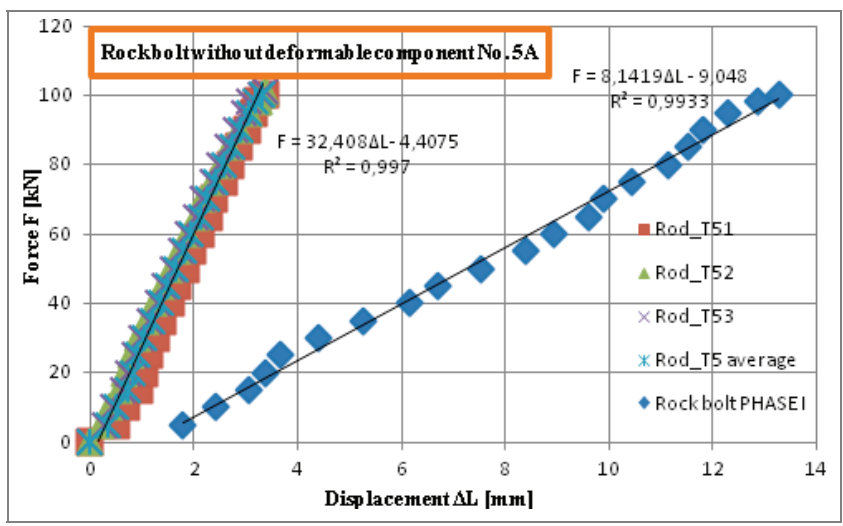

Fig. 35. Detailed loading characteristics for the components of the rock bolt support No. 5A

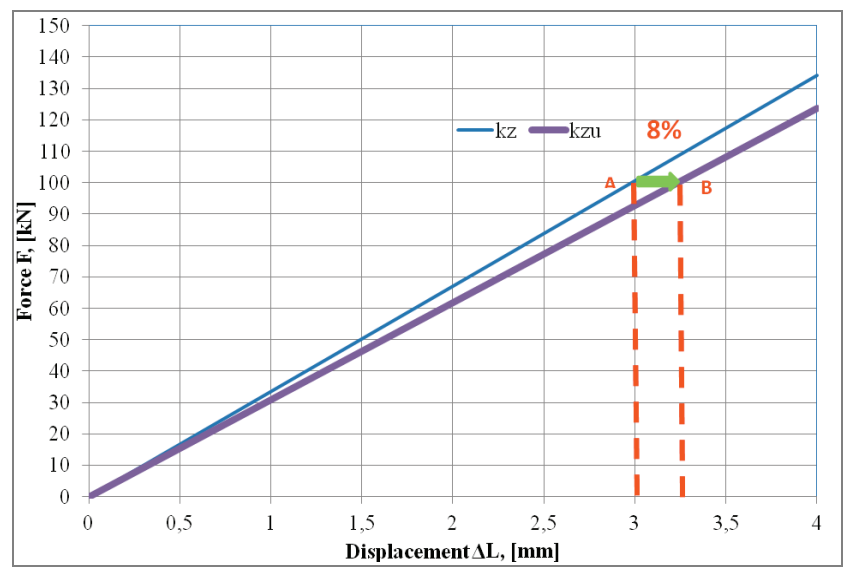

Fig. 36. The impact of the deformable component on the change of bolt rod stiffness coefficient $\mathrm{kz}$

Considerably greater changes were recorded as regards total displacements of the system, both in Phase I and Phase II loading. The highest decrease in the displacement for the rock bolt with increased deformability, up to $14 \mathrm{~mm}$, occurs in Phase I (elastic phase) which is $100 \%$ lower when compared to the rock bolt without increased deformability (transition from $\mathrm{C}$ to $\mathrm{D}$ ), see Fig. 37. In fact, the rock bolt shows greater stiffness within this range.

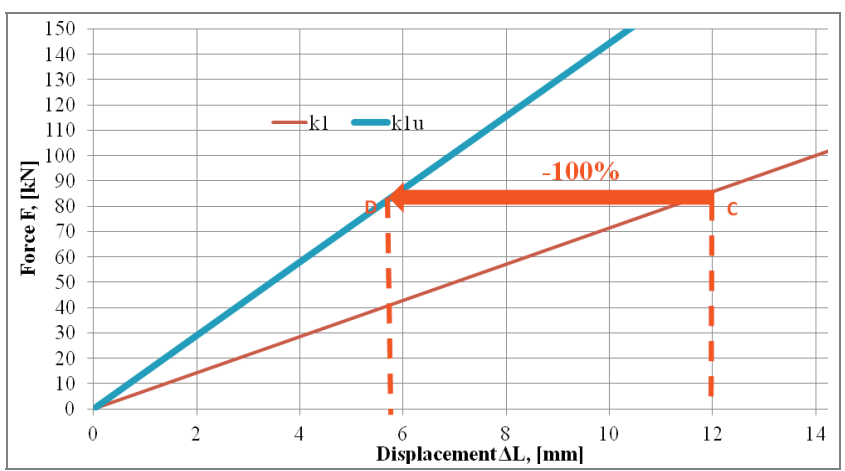

Fig. 37. The impact of the deformable component on the rock bolt stiffness coefficient $k_{1}$ under loading - Phase I

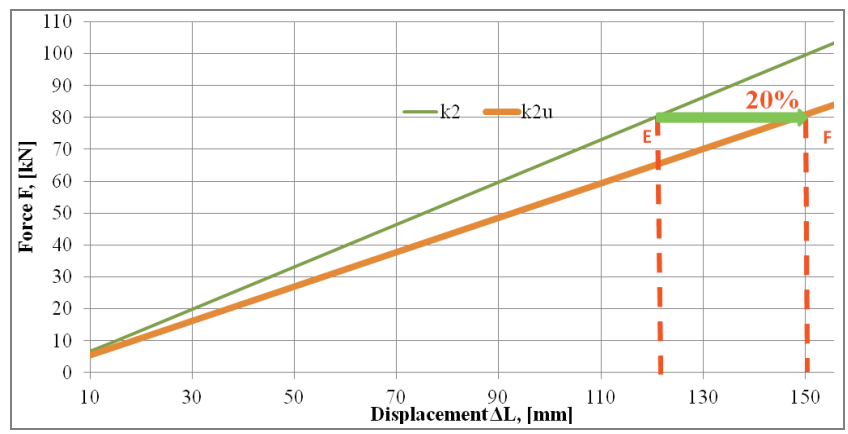

Fig. 38. The impact of the deformable component on the rock bolt stiffness coefficient $k_{2}$ under loading - Phase II

In Phase II, strains (plastic) occur within range of up to ca. $140 \mathrm{~mm}$. In this case, the increase of deformability is about $20 \%$ higher system displacement (transition from E to F), see Fig. 38. It can therefore be stated that using the deformable component in Phase I loading, that is, up to ca. $100 \mathrm{kN}$, makes the entire system stiffer, with slight drop in the stiffness of the bolt rod itself. Only further increment of loading and strain in Phase II causes lower stiffness of the system "rock bolt-head-deformable component".

The load-displacement characteristics for the rock bolt support with a deformable component presented in Figs. 17, 19, 21, 23 and 25 is characterized by the possibility of distinguishing three characteristic ranges in its functioning. The first, from $0 \mathrm{kN}$ up to $90 \mathrm{kN}$, indicates an incomplete compression of the disk springs. Within this range, the profiled rock bolt washers work within the elastic range and the height between the two rock bolt washers is shortened. The 
second range, from $90 \mathrm{kN}$ up to $105 \mathrm{kN}$, indicates plastic deformation of the rock bolt washers. At this stage, the height between the two rock bolt washers increases, caused by washer material plastic deformation (inner part of the washer undergoes plastic deformation towards the inside of the disk springs, whereas the outer part of the washer gets deformed in the opposite direction). The third operation range of the deformable component, from $105 \mathrm{kN}$ up to $120 \mathrm{kN}$, means that the load is taken up by the disk springs. In this range, the height between the two rock bolt washers decreases again, and the disk springs undergo further partial compression.

\section{CONCLUSIONS}

Generally, different constructions of yielded rock bolts are addressed, especially to dynamic loading conditions in underground mines, reducing their failure/rupture risk; however, practically, this kind of rock bolt works most of the time under static loading. Based on the tests of stiff rock bolts equipped additionally with an original deformable component, full characteristics of yielded rock bolts working under static loading were determined.

It has been found that the deformable component increases bolt rod displacement by $8 \%$, as compared with stiff bolt, at the loading force level of $100 \mathrm{kN}$ (minimum loading capacity required for rock bolts in metal ore mines according to Polish mining law).

Further displacement of the yielded rock bolt, up to $14 \mathrm{~mm}$ in Phase I, is lower by $100 \%$ as compared to the stiff rock bolt under the same loading force. Phase II loading, with plastic deformation of the deformable component, is characterised by $20 \%$ increase in displacement of the rock bolt. As a result of the use of the deformable component, the rock bolt can be loaded with its nominal force in the underground excavation and transfer greater displacement of the roof, especially in mines operating in sedimentary, laminated rocks.

Although the advantages of using the deformable component under dynamic phenomena are beyond the scope of this paper, there are numerous research works on the subject, some of which are included in the bibliography.

\section{ACKNOWLEDGEMENT}

This study was developed as part of the statutory work No. 11.11.100.005

\section{REFERENCES}

[1] Biliński J., Katulski A., KondRacki R, RzePecki W., Zachowanie się obudowy kotwiowej $w$ aspekcie drgań górotworu pochodzacych od robót strzałowych, Zeszyty Naukowe AGH - Górnictwo, 1987, 129, 12-20.

[2] Burtan Z., Zorychta A., CieŚliK J., Chlebowski D., Influence of mining operating conditions on fault bahavior, Archives of Mining Science, 2014, 59(3), 691-704.

[3] CAI M., Principles of rock support in burs-prone ground, Tunnelling and Underground Space Technology, 2013, 36, $46-56$.

[4] CAMPoli A., OldSen J., Wu R., Yielding bolt support for burst prone working, Proceedings of Seventh International Symposium: Rockbolting and Rock Mechanics in Mining, Aachen, 2012, 205-212.

[5] Charette F., Plouffe M., A new rock bolt concept for underground excavations under high stress conditions, Proceedings of 6th International Symposium on Ground Support in Mining and Civil Engineering Construction, Johannesburg, 2008, 225-240.

[6] CHEN Y., Li C.C., Performance of fully encapsulated rebar bolts and D-Bolts under combined pull-and-shear loading, Tunnelling and Underground Space Technology, 2015, 45, 99-106.

[7] Corigliano M., Scandella L., Barla G., Lai C.G., PAOLUCCI R., Seismic analysis of deep tunnels in weak rock: A case study in southern Italy, Bulletin of Earthquake Engineering, 2011, 9(4), 975-995.

[8] DęBKowsKi R., RzEPECKI W., TURBAK A., Wybrane aspekty wspótpracy nośnych podktadek kotwowych ze stropem, [in] D. Flisiak (ed.), Geotechnics and civil engineering 2004: XXVII Winter School of Strata Mechanics, Zakopane, 14-19 March 2004, Wydawnictwo KGBiG AGH, 2004, 1053-1056.

[9] He M., Gong W., Wang J., Qi P., Tao Z, Du S, Peng Y., Development of novel energy-absorbing bolt with extraordinarily large elongation and constant resistance, International Journal of Rock Mechanics and Mining Science, 2014. 67, $29-42$.

[10] http://www.arnall.com.pl

[11] http://www.garfordcablebolts.net.au

[12] http://www.interram.pl

[13] http://www.malmfalten.se

[14] JęDRZeJewski A., Planeta S., SiewIerski S., Wplyw rodzaju mieszanek gumowych na nośność kotwi, Przegląd Górniczy, 1975, 10, 409-414.

[15] KaISER P.K., CAI M., Design of rock support system under rockburst condition, Journal of Rock Mechanics and Geotechnical Engineering, 2012, 4(3), 215-227.

[16] Kang H., Wu Y., GAO F., LIN J., JiAng P., Fracture characteristics in rock bolts in underground coal mine roadways, International Journal of Rock Mechanics and Mining Science, 2013, 62, 105-112.

[17] KoRZENIOWSKI W., Ocena stanu podziemnych wyrobisk chodnikowych $i$ komorowych na podstawie empirycznych metod badawczych, Rozprawy - Monografie, nr 156. Uczelnianie Wydawnictwa Naukowo-Dydaktyczne AGH, Kraków, 2006.

[18] KorZeniowski W., SKrzypKowSKi K., Herezy Ł., Laboratory method for evaluating the characteristics of expansion rock bolts subjected to axial tension, Archives of Mining Science, 2015, 60(1), 209-224. 
[19] KorZENIOWSKI W., SKrZYPKOwSKI K., Metody badania górotworu kotwami przy obciązeniach dynamicznych, Przegląd Górniczy, 2011, 3-4, 1-8.

[20] Lanzano G., Bilotta E., Russo G., Tunnels under seismic loading: a review of damage case histories and protection methods, [in:] G. Fabbrocino, F.S. Magistris (eds.), Strategies for reduction of the seismic risk, Publisher StreGa 2008, 65-75.

[21] Li C.C., A new energy - absorbing bolt for rock support in high stress rock masses, International Journal of Rock Mechanics and Mining Science, 2010, 47(3), 396-404.

[22] Li C.C., Doucet C., Performance of D-bolts under dynamic loading, Rock Mechanics and Rock Engineering, 2012, 45(2), 193-204.

[23] Lu Y., Wang L., Zhang B., An experimental study of a deformable support for roadways constructed in deep broken soft rock under high stress, Mining Science and Technology, 2011, 21(6), 839-844.

[24] MajcherczyK T., Niedbalski Z., MaŁkowski P., BEDNAREK Ł., Analysis of deformable steel arch support with rock bolts in mine roadways stability aspect, Archives of Mining Science, 2014, 59(3), 641-654.

[25] MALmGRen L., NoRdLund E., Interaction of shotcrete with rock and rock bolt - A numerical study, International Journal of Rock Mechanics and Mining Science, 2008, 45(4), 538-553.

[26] MAZAIRA A., KoniceK P., Intense rockburst impacts in deep underground construction and their prevention, Canadian Geotechnical Journal, 2015, 52(10), 1426-1439.

[27] Miller A.L., Analysis and redesign of mine bearing plates, Journal of Applied Science and Engineering Technology, 2007, 1, 27-32.

[28] Nierobisz A., Deformable Bolts Research Results, Sobczyk and Kicki (eds.), Taylor and Francis Group, International Mining Forum, 2007.

[29] NiEROBISZ A., The model of dynamic loading of rockbolts, Archives of Mining Science, 2006, 51(3), 453-470.

[30] OleR R., DSI New Developments in Yieldable Rock Bolts. Dynamic Ground Support Applications Symposium, Sudbury, 2012.

[31] OrTLePp W.D., Bornman J.J., ERASMus N., The Durabar a yieldable support tendom - design rationale and laboratory results, Rockbursts and Seismicity in Mines - RaSiM5, South African Institute of Mining and Metallurgy, 2001.

[32] PN-EN 10002-1, Metale. Próba rozciagania. Część 1: Metoda badania $w$ temperaturze otoczenia, 2004.
[33] RZEPECKI W., BILIŃSKI J., Niektóre zagadnienia związane $z$ konstrukcja kotwi przystosowanych do pracy $w$ warunkach drgań górotworu, I Konferencja Naukowo-Techniczna „Obudowa kotwiowa jako skuteczny sposób zabezpieczania wyrobisk w kopalniach rud miedzi”, Lubiatów. Centrum Badawczo-Projektowe Miedzi „Cuprum” Sp. z o.o., Wrocław, 1997.

[34] SIEWIERSKI S., Wplyw obciażenia udarowego na pracę kotwi, Przegląd Górniczy, 1980, 2, 79-86.

[35] SKRZYPKOWSKi K., Roof bolting in terms of dynamic hazards, Gospodarka Surowcami Minerlanymi, 2008, 24(3/3), 305-316.

[36] SKRZYPKOWSKi K., ZAGÓRSKI K., DUdEK P., Zastosowanie drukarki $3 D$ do produkcji prototypowej podkładki kotwowej, Przegląd Górniczy, 2016, 3, 52-56.

[37] St-Pierre L., Hanassi F.P., Radziszewski P.H., Oullet J., Development of a dynamic model for a cone bolt, International Journal of Rock Mechanics and Mining Science, 2009, 46(1), 107-114.

[38] TAJduś A., CAŁA M., TAJduŚ K., Geomechanika $w$ budownictwie podziemnym: projektowanie $i$ budowa tuneli, Wydawnictwa AGH, Kraków 2012.

[39] Wang G., Wu X., Jian Y., Huang N., Wang S., Quasistatic laboratory testing of a new bolt for energy-absorbing applications, Tunneling and Underground Space Technology, 2013, 38, 122-128.

[40] Wang J., Zeng X., Zhou J., Practices on rockburst prevention and control in headrace tunnels of Jinping II hydropower station, Journal of Rock Mechanics and Geotechnical Engineering, 2012, 4(3), 258-268.

[41] Willis D., Roby J., Askilsrud O.G., Extreme machine modifications in different ground at the world's second deepest civil works tunnel, Proceedings in North American Tunneling, edited by M. Fowler, R. Palermo R., R. Pintabona and Smithson M. (eds.), Published by the Society of Mining, Metallurgy and Exploration, Inc., 2012, 153-162.

[42] Wu Y.K., OldSEn J., Development of a New Deformable Rock Bolt - Yield-Lok Bolt, 44th U.S. Rock Mechanics Symposium and 5th U.S. - Canada Rock Mechanics Symposium, Salt Lake City, Utah, American Rock Mechanics Association, 2010.

[43] XU N.W., Li T.B., DAi F., Zhang R., TANG C.A., TANG L.X., Microseismic Monitoring of Strainburst Activities in Deep Tunnels at the Jinping II Hydropower Station, China, Rock Mechanics and Rock Engineering, 2016, 49(3), 981-1000. 